УДК $811.161 .2 ’ 161.2$

DOI:

Оксана Серняк, кандидат педагогічних наук, доцент кафедри англійської філології та методики навчання англійської мови

Тернопільського національного педагогічного університету імені Володимира Гнатюка

\title{
ПРОФЕСІЙНО-ФАХОВА ПІГГОТОВКА ВЧИТЕЛЯ ІНОЗЕМНОЇ МОВИ ДЛЯ НОВОЇ УКРАЇНСЬКОЇ ШКОЛИ
}

У статті проаналізовано аспекти професійної підготовки вчителя іноземної мови для нової украӥнської школи. Досліджено особливості педагогічних технологій колективного навчання, специфіку формування креативного та критичного мислення у процесі навчання іноземної мови. Основними компетентностями у професійній підготовці сучасного вчителя іноземної мови визначено комунікативність, креативність, критичне мислення та здатність до співпрачі. Продемонстровано зразки форм кооперованого навчання, мовленнєвих завдань для формування критичного та креативного мислення

Ключові слова: комунікативна компетентність; креативність; критичне мислення; здатність до кооперачії; іншомовна мовленнєва ситуачія.

Jim. 15.

Oksana Sernyak, Ph.D.(Pedagogy), Associate Professor of the English Philology and Methods of Teaching of English Language Department Ternopil Volodymyr Hnatyuk National Pedagogical University

\section{PROFESSIONAL TRAINING OF FOREIGN LANGUAGE TEACHERS FOR THE NEW UKRAINIAN SCHOOL}

The article analyzes some aspects of the professional training of a foreign language teacher for the new Ukrainian school. There have been investigated the peculiarities of cooperative learning in the process of studying English, specific features of creative approach to teaching a foreign language and the development of critical thinking in the process of teaching a foreign language. It has been revealed that the main competencies in the professional training of a modern foreign language teacher are communication, creativity, critical thinking and ability to cooperate. Models of some forms of cooperative learning, speaking tasks for critical and creative thinking, as well as communication techniques in teaching foreign languages have been demonstrated.

The purpose of teaching a foreign language is the formation of students' communicative competence. The task for the EFL teacher is to organize meaningful interaction between the student and teacher, student and student in the process of foreign language communication.

In the process of learning a foreign language, cooperation is required. Necessary conditions for the implementation of cooperative activities are the following: the presence of the common goal of the activity; common understanding of the task; meaningful communication between the participants.

The introduction of creative technologies involves: the students' independent search for ways and options for solving the problem; unusual working conditions; the active use of acquired knowledge in unfamiliar conditions. Non-standard tasks can be represented in the form of role-plays and business games, contests and other tasks with elements of creativity (dramatization, linguistic fairy tales, "investigation", etc.).

Critical thinking involves a set of stages: the analysis of the information personal awareness and understanding of the problem; active exchange of views with other participants; estimation of variety of considerations; choosing the right option; processing the new knowledge into your own.

Keywords: communicative competence; creative thinking; critical thinking; ability to cooperate; foreign language speaking situation.

B ступ. Сьогодні в Україні відбуваються важливі перетворення в усіх сферах суспільного життя, зокрема в освіті. Ключовою реформою Міністерства освіти і науки став проект під назвою "Нова українська школа".

Як зазначено у Концепції реалізації державної політики у сфері реформування загальної середньої освіти "Нова українська школа" на період до 2029 року, державним завданням $\epsilon$ забезпечення проведення докорінної та системної реформи загальної середньої освіти в Україні. Основна увага має бути звернена на учня нової української школи завдяки запровадженню принципу дитино-центризму як орієнтації на потреби учня. Міністерство освіти позиціонує НУШ як школу, у якій буде приємно навчатись, i яка даватиме учням не тільки знання, як це відбувається зараз, а й вміння застосовувати їх у житті. Згідно з реформою випускник нової української школи має бути цілісною всебічно 


\section{ПРОФЕСІЙНО-ФАХОВАПІГОТОВКА ВЧИТЕЛЯ ІНОЗЕМНОӤ МОВИ ДЛЯ НОВОЇ УКРАЇНСЬКОЇ ШКОЛИ}

розвиненою особистістю, здатною до критичного мислення, патріотом з активною позицією, який здатний приймати відповідальні рішення, конкурувати на ринку праці і навчатися впродовж життя [2].

Центральною фігурою освітнього процесу був і залишається вчитель - фахівець у роботі 3 школярами різного віку, до якого НУШ ставить нові вимоги. Тому, сьогодні особлива відповідальність лежить на вищій педагогічній школі, яка здійснює професійну підготовку вчителів для нової української школи.

Метою статті є аналіз специфіки фахової підготовки вчителів на сучасному етапі та висвітлення практичного досвіду формування професійної компетентності майбутнього вчителя іноземної мови.

Сьогодні фахова підготовка вчителя іноземної мови у педагогічних ЗВО спрямована на засвоєння майбутнім спеціалістом нового змісту освіти і набуття ним ключових компетентностей, необхідних для успішної професійної самореалізації особистості кожного майбутнього фахівця. За експертними оцінками найбільш успішними на ринку праці в найближчій перспективі будуть фахівці, які вміють навчатися впродовж життя, критично мислити, ставити цілі та досягати їх, працювати в команді, спілкуватися в багатокультурному середовищі та володіють іншими уміннями [2].

Аналіз вищезгаданого дозволяє звернути увагу на принцип “чотирьох К”, як уособлення чотирьох компетентностей, без яких складно уявити фахівця майбутнього, а саме комунікативності, креативності, критичного мислення та кооперації. Вищеперераховані навички вважаються основними професійними навичками майбутнього. В методиці навчання іноземних мов це навички, що в англійській мові починаються 3 літери C (communication, creativity, critical thinking and cooperation/collaboration), якими має володіти кожен і вчитель сучасної школи.

Педагогічні ідеї, згадані вище, не є зовсім новими у методиці навчання іноземних мов. До прикладу, формуванню комунікативних навичок у іншомовному спілкуванні присвячено низку досліджень вітчизняних методистів (П. Бех, О. Вишневський, С. Ніколаєва, Н. Скляренко). Проблема колективного/кооперованого навчання вивчалася В. Вихрущ, Н. Пожар, О. Пометун, О. Серняк, О. Ярошенко. Критичне мислення стало темою наукових пошуків таких українських науковців як С. Мірошник, В. Мисан, С. Терно, С. Тимоха. Дослідження О. Акімової, І. Гриненка, О. Смчик, Є. Лебединського, Ю. Чапюк присвячені формуванню креативного/творчого мислення у різних галузях освіти.

Проте, незважаючи на значні досягнення у теоретичних дослідженнях, слід визнати, що вчителі іноземних мов української школи далеко неповно використовують потенціал “чотирьох C" на практиці, дотримуючись традиційного підходу у навчанні іноземних мов, який, фактично, замінює навчання практичного іншомовного мовлення на занятті 3 іноземної мови навчанням мовних правил. Негативним наслідком застосування традиційного, підтримуючого підходу до навчання іноземної мови $€$ те, що на практиці, у практичному спілкуванні іноземною мовою учні “багато пам'ятають, але мало вміють” [1,90]. Навіть на факультетах іноземних мов, де найшвидше запроваджують нові методики навчання іноземних мов, знанням про мову часто надається більше значення, ніж практичним умінням і навичкам користування іноземною мовою [7].

Означене протиріччя спонукає ще раз проаналізувати причини такого явища та запропонувати практичні шляхи покращення ситуації.

На наше переконання, у професійній підготовці вчителів іноземної мови в педагогічному вузі слід звертати увагу майбутніх вчителів, що метою кожного урокуз іноземної мови на будь-якому рівні $\epsilon$ здійснення іншомовної комунікації, яка $\epsilon$ мовленнєвою взаємодією суб' єктів іншомовного спілкування, мовленнєвим обміном інформацією, ідеями чи почуттями комунікатора та реципієнта.

Майбутній вчитель іноземної мови повинен усвідомлювати, що його роль полягає не стільки у наданні учням інформації, (адже різні факти чи дані можна знайти в Інтернеті чи бібліотеці), скільки в забезпеченні можливості для учнів критичної обробки у процесі обговорення наявної інформації у процесі іншомовного мовлення.

Метою навчання іноземної мови на сучасному етапі $\epsilon$, перш за все, формування комунікативної компетентності, яка передбачає уміння та навички іншомовного спілкування. Іншими словами, метою кожного уроку EFL повинна бути змістовна взаємодія між учнем і вчителем, учнем і учнем, учнем і змістом вивченого матеріалу у процесі іншомовного спілкування.

Іншомовне спілкування людей в реальному житті відбувається завдяки виникненню потреби в реалізації певного комунікативного наміру. Тому, на занятті іноземної мови вчитель, перш за все, здійснює організацію іншомовного спілкування, яка полягає у створенні сприятливих умов для здійснення іншомовної комунікації всіма учасниками. 


\section{ПРОФЕСІЙНО-ФАХОВАПДГОТОВКА ВЧИТЕЛЯ ННОЗЕМНОӤ МОВИ ДЛЯ НОВОЇ УКРАЇНСЬКОЇ ШКОЛИ}

Цілеспрямована організація іншомовного спілкування та управління означеним процесом можлива у забезпеченні вчителем іншомовних мовленнєвих ситуацій, які спонукають учасників до здійснення іншомовного спілкування один 3 одним. У результаті в учнів 3'являється потреба до спілкування, коли вони вимушені активізувати свої творчі здібності, мобілізувати свою увагу, використовувати свою пам'ять для вирішення комунікативного завдання. Такі ситуації називають мовленнєвими або комунікативними. Вони завжди містять у собі стимул до мовлення, бажання взаємодіяти мовленнєво у процесі вирішення проблеми [5].

Наведемо приклади іншомовних мовленнєвих ситуацій, які застосовуємо на заняттях з практики англійської мови.

1. A : You are gaining wait. It worries you very much. Complain about it to your friend asking for some advice about an effective diet.

B: Give some advice to your partner who wants to lose weight. Use reasons and specific examples to support your answer.

2. A : You have an intension to try to get a job and work this summer to get some money to be independent of your parents.

B: Give some advice to your partner who wants to get a job. Use reasons and specific examples to support your answer.

3. A: You are going to study in another city where you have to find a place to live. Talk to your friend asking for some advice.

B: Give your partner some advice about choosing a place to live taking into account location, size of accommodation, finances and other features. Use reasons and specific examples to support your answer.

Разом $з$ тим, на ефективність комунікації впливає наявність зворотного зв'язку, який $є$ реакцією реципієнта на повідомлення комунікатора. Зворотний зв’язок робить комунікацію двостороннім процесом. Чим оперативніший зворотний зв'язок, тим більшою мірою можна очікувати підвищення ефекту комунікації [5].

Проте, аналіз іншомовної мовленнєвої діяльності наших студентів довів, що на практиці у неносіїв мови існує брак умінь експромтного висловлювання та швидкого зворотного зв'язку через недостатне знання розмовних готових мовленнєвих одиниць і заповнювачів мовчання, що демонструє недостатній рівень сформованості у них умінь починати і підтримувати розмову іноземною мовою через розгубленість і побоювання перед спілкуванням.
Подолання вищезгаданих недоліків можливе упроцесі тренування у класі готових мовленнєвих одиниць (speech units) та розмовних мовленнєвих формул (conversational formulas and patterns) та зразків для щоденного спілкування. Їх тематика охоплює ситуації привітання, запрошення, здивування, вираження подяки, компліменту, вибачення, скарги, попередження, співчуття, прощання.

Практика доводить, що формування іншомовної комунікативної компетентності сучасного учня можливе лише у процесі успішної реалізації міжособистісної взаємодії педагога 3 учнем, з усім учнівським колективом, а також взаємодії між самим учнями - суб'єктами навчально-виховного процесу. 3 цією метою у центр розгляду сучасні дослідження з методики навчання іноземних мов ставлять навчальну діяльність відображенням, предметно, у якій головними чинниками є взаємодія учасників навчально-виховного процесу, їх особистісне спілкування у спільній навчально-пізнавальній діяльності.

Тому, визначальною стратегією навчання іноземної мови є застосування колективних форм організації навчання, які передбачають реалізацію об’єктивної необхідності учнів у співпраці та їх суб'єктивної потреби у спілкуванні, а саме: усвідомлення школярами спільної мети навчальної діяльності, об'єднання зусиль усіх учасників та цілеспрямований розподіл праці 3 метою виконання спільного навчального завдання, взаємовплив та взаємо-відповідальність, координованість та узгодженість дій, взаєморозуміння, взаємоконтроль та взаємовигоду між членами навчального об'єднання у процесі розв'язання колективного завдання $[7,6]$.

У психолого-педагогічній літературі поняття “колективна діяльність“ доповнюється терміном “кооперована діяльність”, визначальними характеристиками якої $\epsilon$ навчання учнів у співпраці, об’єднання у навчальну команду для спільного виконання навчального завдання, за умови, що вони координують спільні дії у процесі навчально-пізнавальної діяльності на шляху до спільної мети і дістають спільну винагороду за успішно виконане завдання [11].

У процесі аналізу проблеми застосування колективної діяльності як однієї з організаційних форм управління навчально-пізнавальної діяльності вчені називають кооперацією дій. Необхідними умовами здійснення кооперованої діяльності є наявність загальної, спільної для учасників мети діяльності, усвідомлення завдання партнерами та мовленнєве спілкування між 


\section{ПРОФЕСІЙНО-ФАХОВАПДГОТОВКА ВЧИТЕЛЯ ІНОЗЕМНОӤ МОВИ ДЛЯ НОВОЇ УКРАЇНСЬКОЇ ШКОЛИ}

партнерами 3 метою досягнення спільної мети. Забезпечення означених умов сприятиме ефективній та продуктивній діяльності у групі.

Проблема колективного навчання $\epsilon$ актуальною і в зарубіжній педагогіці. Зарубіжні вчені схиляються до термінології коопероване навчання / cooperative learning, групове навчання / group work, навчання у команді / STL / Student Team Learning, навчання однолітків / peer learning / LT Learning Together“ $[12 ; 13 ; 14]$.

Колективна навчально-пізнавальна діяльність відрізняється від традиційного навчання, основою якої є фронтальні та індивідуальні види навчальнопізнавальної діяльності, коли цілий клас чи групи учнів у класі працюють над тими самими завданнями і змагаються один із одним за винагороду. Така організація навчального процесу руйнує різні види взаємодії у навчанні. За таких умов учні знаходяться у ситуації негативної взаємозалежності, де успіх одного учня відбувається у порівнянні, чи на фоні неуспіху інших.

Тому, впровадження колективної навчальнопізнавальної діяльності у процесі вивчення іноземних мов сприяє забезпеченню таких важливих принципів як злиття процесів спілкування і навчання, нерозривність навчально-пізнавальної діяльності учнів та іншомовного спілкування, а також принцип активності, який передбачає високий рівень інтелектуальної, емоційної та іншомовної мовленнєвої діяльності у оволодінні іноземними мовами.

Наведемо зразок однієї з форм кооперованого навчання, під назвою “Мозаїка” (“Jig-saw”). Означена технологія використовується для створення на занятті ситуації, яка дає змогу студентам працювати разом для засвоєння великої кількості інформації за короткий проміжок часу. Заохочує учнів допомагати один одному вчитися, навчаючи. Організація роботи передбачає наступні кроки [8].

1. Підбір вчителем матеріалу (великий за обсягом інформаціï) необхідного для уроку, підготовка індивідуального інформаційного пакету для кожного учасника.

2. Організація “домашньої” групи з трьох учасників, які ідентифіковані відмінними кольорами з різним пакетом інформації. Ознайомлення учасників зі своїм навчальним матеріалом. Завдання домашніх груп опрацювати інформацію та опанувати нею на рівні, достатньому для обміну ичією інформацією з іншими.

3. Перехід учасників з “домашньої” групи до “експертної” групи, у якій збираються учасники, ідентифіковані одним кольором для співпраці над спільним для них аспектом проблеми. Кожна експертна група вислуховує всіх представників домашніх груп $i$ проаналізувати матеріал в цілому, провести його експертну оцінку за визначений час.

4. Після завершення роботи учасники повертаються “додому”. Кожен учень має поділитися інформацією, отриманою в експертній групі з членами своєї “домашньої, групи. Завданням домашніх груп у цьому випадку вже є остаточне узагальнення та корекція всієї інформації.

Практичний досвід роботи доводить, що застосування традиційних прийомів і методів, спрямованих на передачу учням знань в готовому вигляді, особливо у навчанні іноземних мов, $є$ неефективним. Вирішення проблеми полягає у відході від таких методів на користь творчого/ креативного підходу.

Однією із технологій $є$ впровадження нестандартних ситуацій, що сприяє розвитку креативного / конструктивного мислення. Доцільність використання означеної технології обумовлена тим, що вона передбачає цілковите занурення учня у розв'язання проблеми, залучаючи його до активізації мислення, почуттів, знань, інтересу та прагнення до активної діяльності, а в результаті успішного самоконструювання та формування знань, умінь та навичок учнів.

Впровадження в навчальний процес i використання в ньому нестандартних мовленнєвих завдань допомагає викладачеві реалізувати організацію ефективного іншомовного спілкування. Нестандартне завдання має цілий ряд ознак, що дозволяють відмежувати завдання цього типу від традиційних (стандартних). Головна ознака нестандартних завдань - їх зв'язок 3 продуктивною, творчою діяльністю.

Запровадження креативних технологій вимагає від викладача іноземної мови створення нестандартних умов роботи, що забезпечить самостійний пошук студентами шляхів і варіантів вирішення поставленої навчальної задачі та активне застосування набутих знань у незнайомих умовах.

Нестандартні завдання можуть бути представлені у вигляді рольових і ділових ігор, конкурсів та інших завдань з елементами цікавості (реальні та фантастичні ситуації, інсценізації, лінгвістичні казки, ігри у формі розслідування тощо).

У процесі виконання творчого завдання відбувається не відтворення наявного матеріалу чи тексту, а творення власного іншомовного 


\section{ПРОФЕСІЙНО-ФАХОВАПЦГОТОВКА ВЧИТЕЛЯ ІНОЗЕМНОӤ МОВИ ДЛЯ НОВОЇ УКРАЇНСЬКОЇ ШКОЛИ}

дискурсу на основі іншомовних текстів різних жанрів. Тому, завдання викладача - “оживити” традиційну роботу з іншомовними текстами за допомогою створення альтернативного контексту, в якому він буде використовуватися на занятті. Цьому можуть сприяти рольові ігри, симулятивні завдання, мовленнєві установки вчителя.

Креативні види діяльності спонукають студентів до іншомовного спілкування за допомогою зміни і варіювання певних обставин при створенні ситуативного контексту, який набере іншої форми та глибшої актуальності для студентів, мотивуючи їх, роблячи роботу 3 текстом більш цікавою та динамічною, залучаючи емоції та почуття сприйняття. Найбільш поширеними видами означених завдань методисти вважають: антиципаційні (спрямовані на передбачення учнями змісту тексту) та перспективні (орієнтовані на творчу діяльність після читання) [3].

Так, антиципаційні завдання збуджують емоції учнів: цікавість, радість та здивування. Різні почуття сприйняття і можуть включати в себе постановку гіпотез про зміст тексту, місце подій, головних героїв. Цікавим елементом є створення паралельних текстів на основі опорних слів 3 вихідного тексту. Ефективним є застосування малюнків, слайдів, музики тощо. Звернення до емоційної та інтелектуальної сфери студентів, до їхнього внутрішнього світу і життєвому досвіду також актуалізують перетворення тексту у дискурс [3].

Сюрпризна стратегія передбачає забезпечення викладачем інформації, що контрастує із звичними клішованими уявленнями чи порушує автоматизм мислення і сформовані стереотипи. Симулятивні завдання передбачають створення ситуативного контексту на основі вигаданих чи ігрових обставин, які спонукають студента розвернути ситуацію на себе і діяти в умовах заданих обставин, здійснюючи іншомовну діяльність [3].

Прикладом вищезгаданих мовленнєвих завдань $є$ рольова гра під назвою "Купуємо Різдвяні подарунки".

\section{Role play BUYING CHRISTMAS PRESENTS}

Your friend Liz has a big family (Mother, Father, Grandma, Grandpa, elder sister Rosie who is 22; younger brother Jack, aged 19). Give Liz some advice about what kind of present she can buy her folks for Christmas.

Some info about the family:

Sandra Dooley -42 , the mother of 3 children, a family woman who is busy taking care of her family. (tries to look well, she is fond of knitting)

Peter Dooley - 45, the father of 3 children / a bank manager / fond of football/ sensible / gregarious /tolerant/ practical).

Rosie Dooley 22 - a young girl / has just begun to work as an EFL teacher/ pays much attention to appearance/ obsessed with jewelry/ active with many hobbies/ collecting porcelain / antiques/ amateur dramatics/ travelling/)

Jack Dooley 19 - a young fellow / likes the latest pieces of technology/ crazy about computer games/ fond of tennis /

Mathew Dooley - 70, the father of Peter Dooley, a pensioner. His hobby is doing repairs about the house and summer cottage.

Sue Dooley - 68, the mother of Peter Dooley / a pensioner / fond of cooking / baking / gardening / especially flowers/ likes comfort in the house/

Таким чином, застосування креативних технологій у навчанні майбутніх вчителів іноземної мови забезпечує необхідне комунікативне спрямування та слугує засобом у забезпеченні інтерактивного навчання упроцесі вивчення іноземної мови, формує професійну креативну компетентність майбугнього вчителя іноземної мови.

Сьогодні, коли українці вже декілька років живуть в стані інформаційної війни, постійно зіштовхуючись 3 інформаційними фейками, необхідною навичкою для кожного члена суспільства $є$ навичка критичного мислення. Водночас, критичне мислення зараз є модним трендом в освіті [9].

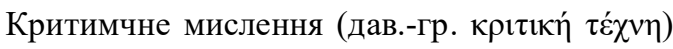
як мистецтво аналізувати $є$ складним i багаторівневим явищем, що спонукає до глибшого аналізу означеного терміну. М. Ліпман визначає критичне мислення як кваліфіковане, відповідальне мислення, що виносить правильні судження, тому що засноване на критеріях. Основним призначенням критичного мислення $\epsilon$ розв'язання проблем (завдань), а головним результатом критичного мислення $є$ прийняття рішення, судження чи ухвали [4].

Критичне мислення $є$ складним процесом творчої переробки інформації, пов'язаної з іiі усвідомленням, переосмисленням такої діяльності. Як інноваційне мислення, критичне мислення полягає в ухваленні ретельно обміркованих та незалежних рішень. Одним із ключових умінь в критичному розмірковуванні $\epsilon$ висунення гіпотез чи формулювання припущень щодо вирішення проблеми [15].

У теорії розвитку критичного мислення у процесі навчання С. Терно позиціонує його як 


\section{ПРОФЕСІЙНО-ФАХОВАПДГОТОВКА ВЧИТЕЛЯІНОЗЕМНОӤ МОВИ ДЛЯ НОВОЇ УКРАЇНСЬКОЇ ШКОЛИ}

сукупність етапів: знайомство з інформацією, iї аналіз, особистісне усвідомлення та розуміння; активний обмін думками 3 іншими учасниками; оцінка розмаїття міркувань; вибір правильного варіанту; переробка нових знань на власні [9]. Водночас, С. Тимоха стверджує, що психологічно критичне мислення базується на прагненні до творчого пошуку та набуття нових знань чи досвіду [10].

На занятті, де студентів спонукають до критичного мислення, учасники ставлять запитання; вчаться оцінювати явища та об’єкти, співвідносячи дослідження 3 певною системою цінностей; висувати гіпотези; помічати факти, що суперечать загальноприйнятій думці; використовувати різні критерії та контексти; вибирати одну із багатьох альтернатив; обгрунтовувати думку; знаходити контраргументи; доводити, добираючи прийнятні, відповідні та несуперечливі докази; спростовувати неадекватні аргументи; узагальнювати та робити висновки [7].

В методиці іноземних мов використовується розмаїття стратегій, які базуються на критичному мисленні: "Сенкан”, “Кубування”, “Есе”, “Дискусія", “Метод прес”, “Виправлення порушеної послідовності”, “Взаємні запитання”, "Письмо в малюнках", “Доповідач-респондент” [6].

Наведемо приклад однієї 3 ефективних стратегій, яка широко застосовується у навчанні іноземної мови. Це - стратегія дискусії під назвою "Акваріум" / "Fishbowl".

Організація роботи, полягає у тому, що студенти об' єднуються у групи по $4-6$ осіб для проведення групової дискусії з метою знайдення спільного рішення. Одна 3 груп сідає в центр аудиторії, отримуючи дискусійне завдання. Студенти, що знаходяться у зовнішньому колі, слідкують за ходом обговорення, роблячи нотатки. По закінченні дискусії, аудиторія вирішує чиї твердження були аргументованими i доведеними. Спостерігачі визначають, хто 3 учасників був найбільш переконливим і чому. Після цього місце в “Акваріумі” займає інша група й обговорює наступну ситуацію.

Пропонуємо теми для дискусій на занятті 3 англійської мови.

1. It is everyone's responsibility to protect the environment. What do you think about such a statement? Use specific reasons and examples to support your opinion.

2. Mobile phones destroy face to face communication among friends and family. Use specific reasons and examples to support your opinion.
3. Our country is in the middle of energy crisis because of the lack of fossil fuels. Talk about the solution of these problems. Use specific reasons and examples to support your opinion.

Таким чином, застосування принципу “чотирьох К” (комунікативності, креативності, критичного мислення та кооперації) у методиці навчання іноземних мов сприяє вдосконаленню процесу вивчення іноземної мови, забезпечуючи активну мовленнєву діяльність студентів, викликає у них бажання висловлюватися іноземною мовою, взаємодіяти із співрозмовником, а головне, стане підгрунтям для фахової підготовки майбутнього вчителя нової іноземної мови, який буде ефективно працювати в новій українській школі.

\section{ЛІТЕРАТУРА}

1. Атанов Г. А. Обгрунтування та сутність діяльнісного підходу до навчання. Педагогіка і психологія професійної освіти, №3, 2002. С. 8593.

2. Концепція реалізації державної політики у сфері реформування загальної середньої освіти "Нова українська школа" на період до 2029 року. URL : htps://mon.gov.ua/ua/tag/nova-ukrainskashkola

3. Кучерява О.А. Формування дискурсивної компетенції студентів філологічних факультетів вищих навчальних закладів: дис. ...кандидата пед. наук : 13.00.02 : у 2-х кн. Одеса, 2008. 229 с.

4. Липман М. Рефлексивная модель практики образования. Thinking in Education. Cambridge, 1991. С. 7-25.

5. Методика навчання іноземних мов у середніх навчальних закладах. / За ред. С.Ю. Ніколаєвої. К.: Ленвіт, 1999. 320 с.

6. Савенко К. Критичне мислення: Навіщо і як його розвивати. URL: http://womo.ua/kritichnemislennya-navishho-i-yak-yogo-rozvivati/

7. Серняк О.М. Формування готовності майбутнього вчителя до педагогічного управління колективною навчально-пізнавальною діяльністю учнів : автореф. дис. ... канд.пед. наук: спец. 13.00.04. Тернопіль, 2008.23 с.

8. Сучасний урок. Інтерактивні технології навчання: Наук.-метод. посібн. / За ред. О.І. Пометун. К.: Видавництво А.С.К., 2004. 192 с.

9. Терно С. О. Критичне мислення - сучасний вимір суспільствознавчої освіти. Запоріжжя: Просвіта, 2009. 268 с.

10. Тимоха С. Теоретичні основи розвитку критичного мислення студентів. Гуманізація навчально-виховного процесу. Випуск LV.Частина II. Слов'янськ, 2011. C. 38-42. URL:// http:// 


\section{ПРОФЕСІЙНО-ФАХОВАПІДОТОВКА ВЧИТЕЛЯ ІНОЗЕМНОӤ МОВИ ДЛЯ НОВОЇ УКРАЇНСЬКОЇ ШКОЛИ}

archive.nbuv.gov.ua/portal/soc_gum/gnvp/ 2011_55_2/8.pdf

11. Ярошенко О.Я. Педагогічні основи групової навчальної діяльності школярів (на матеріалі вивчення хімії): Автореф. дис. ... канд. пед. наук / КНПУ, Київ, 1998. 23 с.

12. Bejarano Y. A cooperative small-group methodology in the language classroom. TESOL Quarterly, 1987. V.21, № 3, P. 483-504.

13. Johnson D. W. and Jonhnson E. P. Joining Together : Group theory and group skills. Englewood Cliffs, N.J: Prentice-Hall, 1987. - 257 p.

14. Long Michael H., Porter, P.A. Group work, interlanguage talk, and second language acquisition. TESOL Quarterly, 1985. V.19, № 2, P. 207-208.

15. Stancato F. Tenure, Academic Freedom and the Teaching of Critical Thinking. College Student Journal. September, 2000.

\section{REFERENCES}

1. Atanov, H. A. (2002). Obgruntuvannia ta sutnist diialnisnoho pidkhodu do navchannia [Substantiation and essence of the activity approach to learning]. Journal Pedagogy and psychology of vocational education, No. 3, pp. 85-93. [in Ukrainian].

2. Koncepciya realizaciyi derzhavnoyi polityky u sferi reformuvannya zagalnoyi serednoyi osvity "Nova ukrayinska shkola" na period do 2029 roku [Concept of implementation of state policy in the field of reforming the general secondary education "New Ukrainian School" for the period up to 2029]. Available at: htps://mon.gov.ua/ua/tag/novaukrainska-shkola [in Ukrainian].

3. Kucheriava, O.A. (2008). Formuvannia dyskursyvnoi kompetentsii studentiv filolohichnykh fakultetiv vyshchykh navchalnykh zakladiv [Formation of discourse competence of students of philological faculties of higher educational institutions]. Candidate's thesis. Odesa. 229 p. [in Ukrainian].

4. Lypman, M. (1991). Refleksyvnaia model praktyky obrazovanyia [Reflexive model of education practice]. Thinking in Education. Cambridge. pp. 7-25. [in Ukrainian].

5. Metodyka navchannia inozemnykh mov u serednikh navchalnykh zakladakh (1999). [Methods of teaching foreign languages in secondary schools]. Educational manual (Ed.). S.Yu. Nikolayeva. Kyiv: Lenvit Publ., 320 p. [in Ukrainian].
6. Savenko, K. (2019). Krytychne myslennia: Navishcho i yak yoho rozvyvaty [Critical thinking: Why and how to develop it]. Available at: http:// womo.ua/kritichne-mislennya-navishho-i-yak-yogorozvivati [in Ukrainian].

7. Serniak, O.M. (2008). Formuvannia hotovnosti maibutnoho vchytelia do pedahohichnoho upravlinnia kolektyvnoiu navchalno-piznavalnoiu diialnistiu uchniv [Formation of readiness of the teacher to be for pedagogical management of collective educational and cognitive activity of students]. Extended abstract of candidate's thesis. 23 p. [in Ukrainian].

8. Suchasnyi urok. Interaktyvni tekhnolohii navchannia (2004). [Contemporary lesson. Interactive Learning Technologies]. Educational manual (Ed.).O.I. Pometun. Kyiv: A.S.K. Publ., 192 p. [in Ukrainian].

9. Terno, S. O. (2009). Krytychne myslennia suchasnyi vymir suspilstvoznavchoi osvity [Critical thinking as modern dimension of social science education]. Zaporizhzhya: Prosvita Publ., 268 p. [in Ukrainian].

10. Tymokha, S. (2011). Teoretychni osnovy rozvytku krytychnoho myslennia studentiv. [Theoretical foundations of the development of students' critical thinking]. Journal Humanization of the educational process. Vol.LV. Part II. Sloviansk, pp. 38-42. Available at: http://archive.nbuv.gov.ua/ portal/soc_gum/gnvp/2011_55_2/8.pdf[in Ukrainian].

11. Iaroshenko, O.Ia. (1998). Pedahohichni osnovy hrupovoi navchalnoi diialnosti shkoliariv (na materiali vyvchennia khimii) [Pedagogical foundations of pupils' group educational activity (on the material of studying of Chemistry)]. Extended abstract of candidate's thesis. 23 p. [in Ukrainian].

12. Bejarano, Y.A. (1987). Cooperative small-group methodology in the language classroom. TESOL Quarterly. vol. 21, No 3, pp. 483-504. [in English].

13. Johnson, D. W., Jonhnson E. P. (1987). Joining Together : Group theory and group skills. Englewood Cliffs, N.J: Prentice-Hall. 257 p. [in English].

14. Long, Michael H., Porter, P. A. (1985). Group work, interlanguage talk, and second language acquisition. TESOL Quarterly.vol.19, No. 2, pp. 20728. [in English].

15. Stancato, F. (2000). Tenure, Academic Freedom and the Teaching of Critical Thinking. College Student Journal. September pp. 23-34. [in English].

Стаття надійшла до редакції 31.01.2019

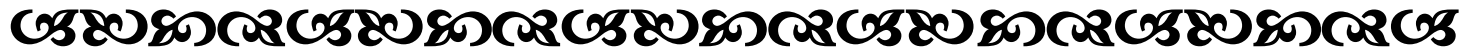

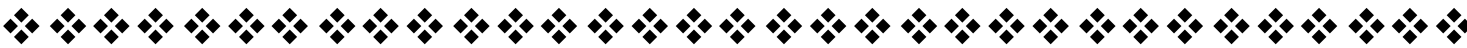

